Original Article

\title{
"FORMULATION AND EVALUATION OF MORONIC ACID LOADED TRANSDERMAL PATCHES"
}

\author{
RITU RANI*, TARANJIT KAUR, AJEET PAL SINGH, AMAR PAL SINGH
}

St. Soldier Institute of Pharmacy, Lidhran Campus, Behind NIT (R. E. C), Jalandhar-Amritsar Bypass NH-1 Jalandhar 144011, Punjab, India Email: reetuchahal27@gmail.com

Received: 01 Aug 2021, Revised and Accepted: 10 Oct 2021

ABSTRACT

Objective: To prepare Transdermal patches of Moronic acid along with various polymers for controlled release action.

Methods: Suitable method such as Solvent Casting Technique of Film Casting Technique are used for the preparation of Transdermal patch.

Results: The prepared Transdermal patches were transparent, smooth, uniform and flexible. The method adopted for the preparation of the system was found satisfactory.

Conclusion: Various formulations were developed by using hydrophilic and hydrophobic polymers like HPMC E5 and EC respectively in single and combinations by solvent evaporation technique with the incorporation of penetration enhancer such as dimethylsulfoxide and dibutyl phthalate as plasticizer. Formulation F7 containing an equal ratio of HPMC E5: EC (5:5) showed maximum and sustained release of $86.814 \pm 0.262$ within 24 h. Kinetic models were used to confirm the release mechanism of the formulations. Moronic acid release from the patches F1 to F7 followed non Fickian diffusion rate controlled mechanism.

Keywords: Controlled DDS, Transdermal DDS, Moronic acid, Transdermal Patch, Solvent evaporation method

(C) 2021 The Authors. Published by Innovare Academic Sciences Pvt Ltd. This is an open access article under the CC BY license (https://creativecommons.org/licenses/by/4.0/) DOI: https://dx.doi.org/10.22159/ijcpr.2021v13i6.1932 Journal homepage: https://innovareacademics.in/journals/index.php/ijcpr

\section{INTRODUCTION}

Conventional systems of medication that require multi-dose therapy are having many problems. The controlled drug delivery is a newer approach is to deliver the drug in to systemic circulation at a predetermined rate. Our system should duplicate continuous intravenous infusion, which not only bypasses hepatic 'first pass' elimination but also maintains a constant, prolonged and therapeutically effective drug level in the body [1].

Transdermal drug delivery system constitutes one of the most important routes for new drug delivery system. Transdermal delivery of drugs offers several advantages over conventional delivery methods. Transdermal delivery, that traditionally uses a patch containing drug substance pressed onto the skin, is non-invasive, convenient and painless, and can avoid gastrointestinal toxicity (e. g. peptic ulcer disease) and the hepatic first-pass metabolism [2].

Moronic acid (3-oxoolean-18-en-28-oic acid) is a natural Triterpenes. Moronic acid can be extracted from Rhus javanica, a sumac plant traditionally believed to hold medicinal applications. The molecule has also been extracted from Mistletoe (Phoradendron reichenbachianum) [3].

Bevirimat, a derivative of the related Triterpenoids betulinic acid, is under development as an anti-HIV drug; however, moronic acid has shown better antiviral profiles in vitro than bevirimat. A particular moronic acid derivative showed potent anti-HIV activity with EC50 values of $0.0085 \mu \mathrm{M}$ against NL4-3, $0.021 \mu \mathrm{M}$ against PI-R (a multiple protease inhibitor resistant strain), and $0.13 \mu \mathrm{M}$ against FHR-2 (an HIV strain resistant to (bevirimat). This derivative has become a new lead for clinical trials and is also active against the herpes simplex virus [4].

\section{MATERIALS AND METHODS}

\section{Method}

Suitable method such as Solvent Casting Technique of Film Casting Technique are used for preparation of Transdermal patch.

\section{Determination of solubility $[5,6]$}

An excess amount of drug was taken and dissolved in a measured volume of distilled water in a volumetric flask to get a saturated solution. The solution was kept for $24 \mathrm{~h}$ at room temperature for the attainment of equilibrium. These solutions were kept for sonication and then the supernatant was filtered using a 0.45-micron whatmann filter paper to separate the undissolved drug particles and diluted suitably and the concentration of Moronic acid in the filtrate was determined spectrophotometrically by measuring at $300 \mathrm{~nm}$.

\section{Determination of partition coefficient [7]}

The partition coefficient of the drug was determined by taking equal volumes of 1-octanol and aqueous solution in a separating funnel. In case of water-soluble drugs, a drug solution was prepared in distilled water, and in case of water-insoluble drugs, a drug solution of was prepared in 1-octanol. Standard solution of the drug was prepared in this phosphate buffer pH 7.4 solution. Octanol $(10 \mathrm{ml})$ was added to an equal volume of this standard drug solution in a separating funnel and was kept for $24 \mathrm{~h}$ at $37 \pm 0.5{ }^{\circ} \mathrm{C}$ with intermittent shaking. Finally, the buffer solution was separated, clarified by centrifugation and assayed for drug content.

\section{FT-IR [8]}

In the preparation of film formulation, drug and polymer may interact as they are in close contact with each other, which could lead to the instability of drug, Preformulation studies regarding the drug-polymer interaction are therefore very critical in selecting appropriate polymers. FT-IR spectroscopy was employed to ascertain the compatibility between Moronic acid and the selected polymers. The pure drug and drug with excipients were scanned separately.

\section{Procurement of standard drug}

Moronic acid was procured from Tokyo Chemical Industry Co. Ltd.

\section{Characterization of moronic acid}

\section{DSC of moronic acid}

Purity profile of the drug was determined by using Differential Scanning Calorimetry (DSC). The latter can be assessed by the melting behavior observed in the recorded thermogram. The main application of DSC to purity relies on the notion that impurities reduce the melting temperature of the drug. The melting temperature is a strong indication 
of drug purity for carrying out DSC of the model drug, $2 \mathrm{mg}$ of sample was placed in an aluminum pan. The pan was crimped using punching press. The sample pan was placed in pan holder of the DSC machine. The sample was run at a ramp rate of $10^{\circ} \mathrm{C} / \mathrm{min}$ from $25^{\circ} \mathrm{C}$ to $300^{\circ} \mathrm{C}$ with a flow rate of $60 \mathrm{ml} / \mathrm{min}$ for nitrogen [1].

\section{Calibration curve of moronic acid}

The standard calibration curve was constructed to obtain a regression line equation to be used for finding out the concentration of drug in samples. Two calibration curves of the drug were plotted; one by RP-HPLC method and one by UV spectrophotometer. Calibration curve by RP-HPLC method was used for assay of drug in gel matrix for entrapment efficiency studies. The other one was plotted by UV spectrophotometer using Ethanolic phosphate buffer (pH 7.4) for carrying out in vitro drug release studies.

\section{Evaluation of transdermal patches}

\section{Physical appearance}

All the prepared patches were visually inspected for color, clarity, flexibility and smoothness.

\section{Thickness uniformity}

The aim of the present study was to check the uniformity of thickness of the formulated films. The thickness of the film was measured at 3 different points using a digital caliper and an average thickness of three reading was calculated.

\section{Weight uniformity [9]}

For each formulation, three randomly selected patches were used. For the weight variation test, 3 films from each batch were weighed individually and the average weight was calculated.

\section{Folding endurance [10]}

The folding endurance was measured manually for the prepared films. A strip of film $(5 \times 5 \mathrm{~cm})$ was cut and repeatedly folded at the same place till it broke. The number of times the film could be folded at the same place without breaking/cracking gave the value of folding endurance.

\section{Percentage moisture absorption [11]}

The films were weighed accurately and placed in the desiccators containing $100 \mathrm{ml}$ of a saturated solution of potassium chloride, which maintains $80-90 \%$ RH. After 3 d, the films were taken out and weighed. The study was performed at room temperature. The percentage moisture absorption was calculated using the formula:

$$
\begin{gathered}
\text { Percentage moisture absorption = Final Weight-Initial } \\
\text { Weight/Initial Weight X } 100
\end{gathered}
$$

\section{Percentage moisture loss}

The films were weighed accurately and kept in a desiccators containing anhydrous calcium chloride. After $3 \mathrm{~d}$, the films were taken out and weighed. The moisture loss was calculated using the formula:

\section{Percentage moisture loss $=$ Final Weight-Initial Weight $/$ Initial Weight X 100}

\section{Water vapors transmission rate [12]}

Glass vials of $5 \mathrm{ml}$ capacity were washed thoroughly and dried to a constant weight in an oven. About $1 \mathrm{gm}$ of fused calcium chloride was taken in the vials and the polymer films of $1.44 \mathrm{~cm}^{2}$ were fixed over the brim with the help of an adhesive tape. Then the vials were weighed and stored in a humidity chamber of 80-90 \% RH condition for a period of 24 $\mathrm{h}$. The vials were removed and weighed at the time interval of $24 \mathrm{~h}$ for three consecutive days to note down the weight gain.

Water vapour transmission rate $=$ Final Weight-Initial Weight/Time $\mathrm{X}$ Area X 100

\section{Tensile strength [13]}

Tensile strength of the film was determined with Universal strength testing machine (Hounsfield, Slinfold, Horsham, U. K.). The sensitivity of the machine was 1 gram. It consisted of two load cell grips. The lower one was fixed and the upper one was movable. The test film of size $(4 \times 1$ $\mathrm{cm} 2$ ) was fixed between these cell grips and force was gradually applied till the film broke. The tensile strength of the film was taken directly from the dial reading in $\mathrm{kg}$. Tensile strength is expressed as follows;

Tensile strength $=$ Tensile load at Break/Cross-Sectional Area

\section{RESULTS}

Preformulation studies/parameters of moronic acid [14]

\begin{tabular}{|c|c|c|c|}
\hline S. No. & Parameters & Inference & \\
\hline 1. & Appearance & Powder & \\
\hline 2. & Molecular Formula & $\mathrm{C}_{30} \mathrm{H}_{46} \mathrm{O}_{3}$ & \\
\hline 3. & Melting point & $317.32^{\circ} \mathrm{C}$ & \\
\hline \multirow[t]{3}{*}{4.} & Solubility & In ethanol & Soluble \\
\hline & & In Chloroform & Soluble \\
\hline & & In DMSO & Soluble \\
\hline 5. & Storage & Desiccate at $-20^{\circ} \mathrm{C}$ & \\
\hline 6. & Partition coefficient & 4.7 & \\
\hline 8. & Enthalpy of Vaporization & $90.7 \pm 6.0 \mathrm{~kJ} / \mathrm{mol}$ & \\
\hline
\end{tabular}

Table 1: Preformulation studies/parameters of moronic acid

Drug excipients compatibility studies

$>$ FT-IR spectrum and values

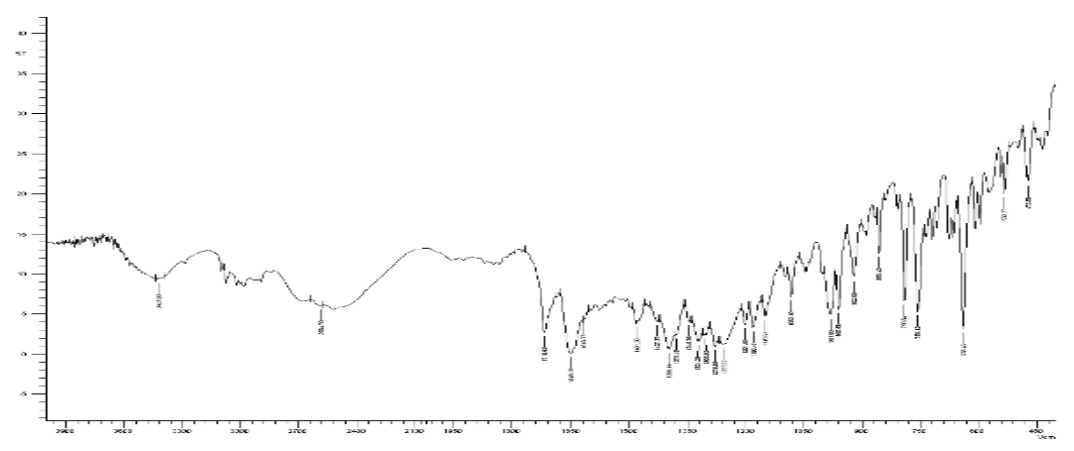

Fig. 1: IR spectrum of pure moronic acid 


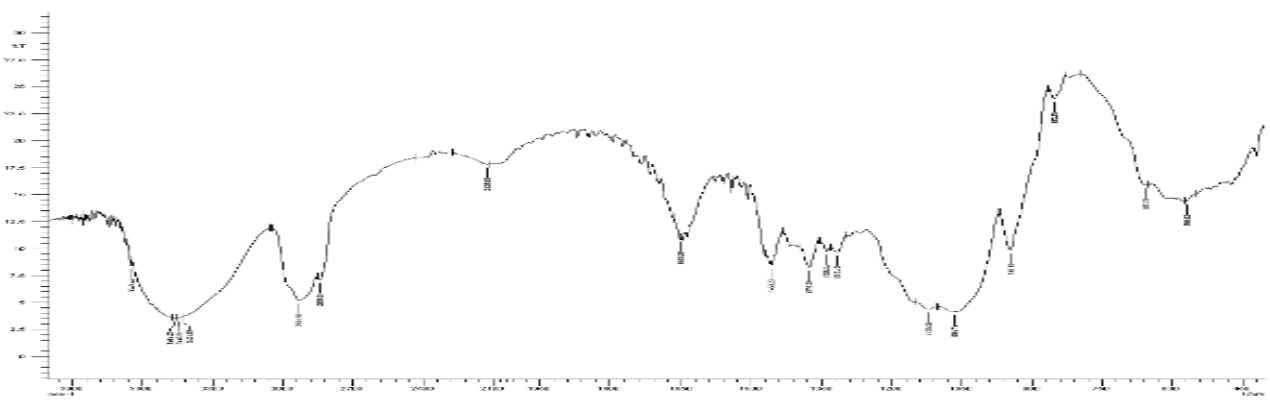

Fig. 2: IR spectrum of pure HPMC E5

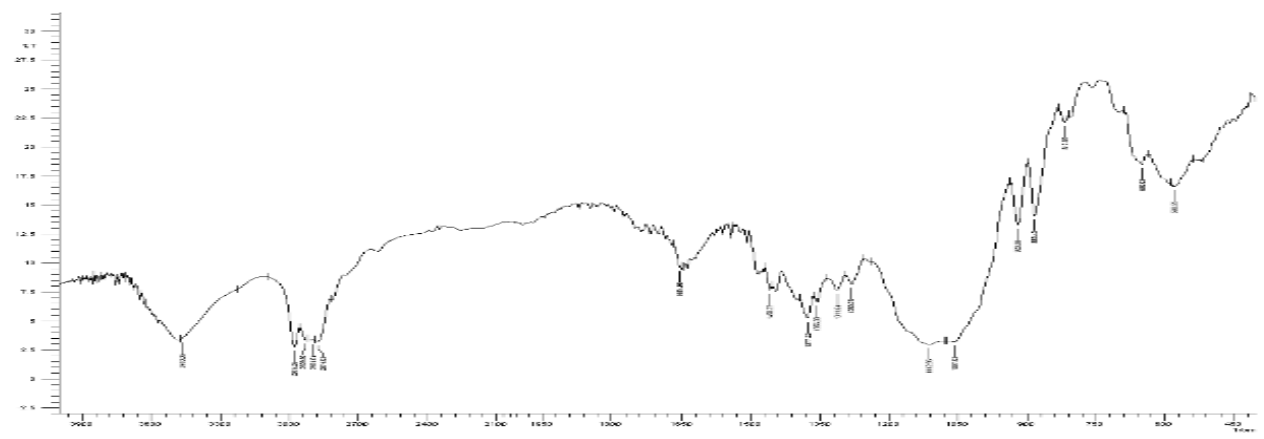

Fig. 3: IR spectrum of pure EC

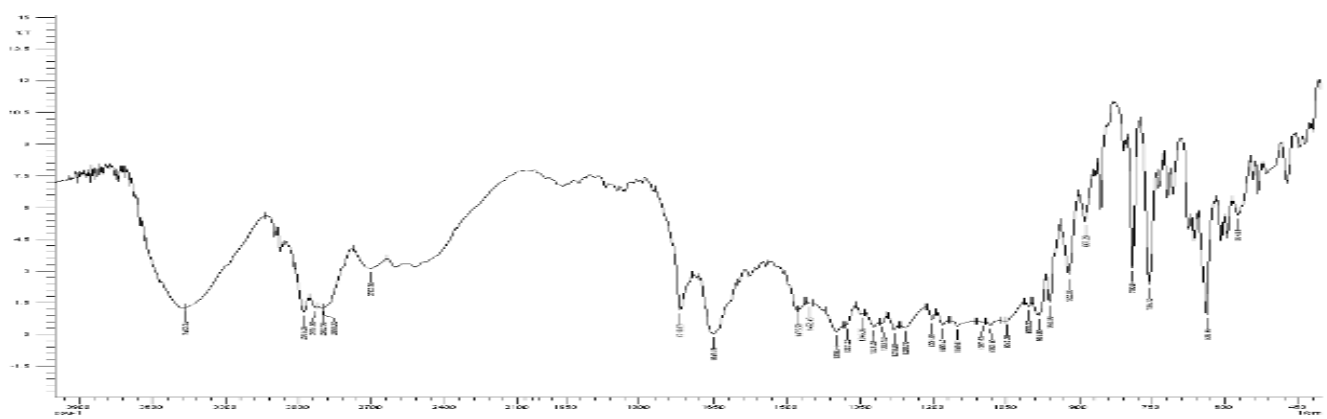

Fig. 4: IR spectrum of moronic acid+HPMC E5+EC mixture

Table 2: FT-IR spectrum values

\begin{tabular}{|c|c|c|c|c|}
\hline S. No. & IR spectrum of & Groups & Peak $\left(\mathrm{cm}^{-1}\right)$ & Stretching/Deformation \\
\hline \multirow[t]{7}{*}{1} & Moronic acid & $\mathrm{N}$-tertiary & 3436 & Stretching \\
\hline & & $\mathrm{CH} 2$ & 2696 & Stretching \\
\hline & & $\mathrm{CH} 3$ & 2348 & Stretching \\
\hline & & $\mathrm{C}=\mathrm{O}$ & 1654 & Stretching \\
\hline & & $\mathrm{C}=\mathrm{C}$ & 1476 & Stretching \\
\hline & & $\mathrm{C}-\mathrm{N}$ & 1394 & Stretching \\
\hline & & $\mathrm{C}-\mathrm{S}$ & 754 & Stretching \\
\hline \multirow[t]{2}{*}{2} & HPMC E5 & $\mathrm{O}-\mathrm{H}$ & 3462 & Stretching \\
\hline & & $\mathrm{C}-\mathrm{O}-\mathrm{C}$ & 1066 & Stretching \\
\hline \multirow[t]{3}{*}{3} & $\mathrm{EC}$ & $\mathrm{CH} 2$ & 2976 & Stretching \\
\hline & & $\mathrm{CH} 3$ & 2874 & Stretching \\
\hline & & $\mathrm{C}-\mathrm{O}-\mathrm{C}$ & 1052 & Stretching \\
\hline \multirow[t]{6}{*}{4} & Physical mixture of drug & N-tertiary & 3434 & Stretching \\
\hline & and polymer & $\mathrm{CH} 3$ & 2928 & Stretching \\
\hline & & $\mathrm{C}=\mathrm{O}$ & 1652 & Stretching \\
\hline & & $\mathrm{C}=\mathrm{C}$ & 1474 & Stretching \\
\hline & & $\mathrm{O}-\mathrm{H}$ & 3466 & Stretching \\
\hline & & $\mathrm{C}-\mathrm{O}-\mathrm{C}$ & 1086 & Stretching \\
\hline
\end{tabular}


Differential scanning calorimetry

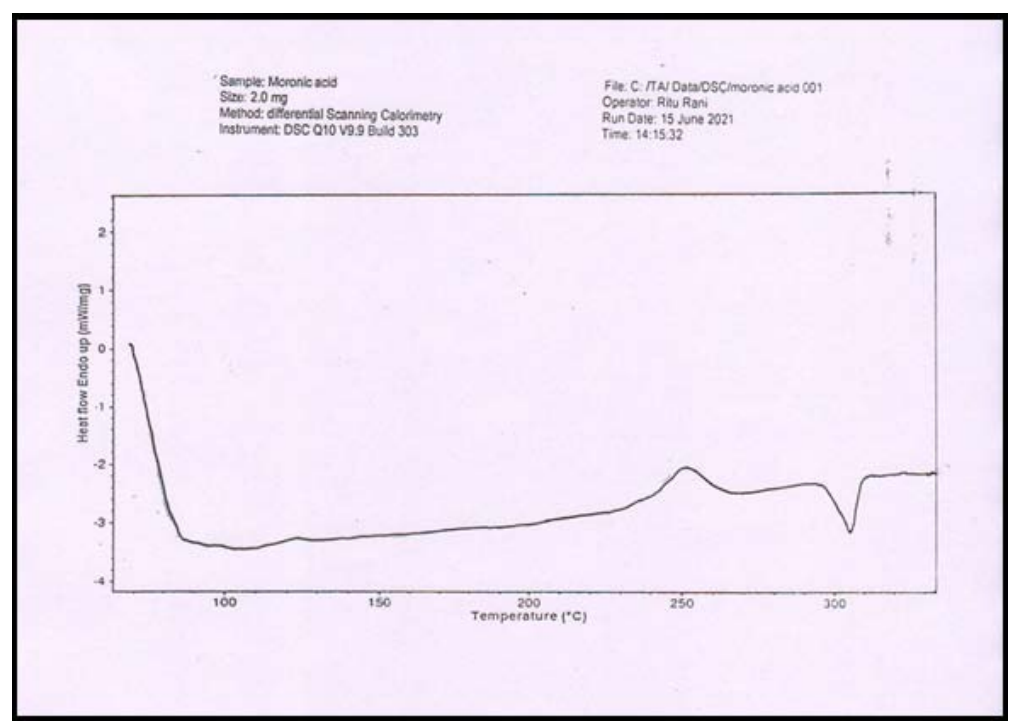

Fig. 5: DSC curve of moronic acid

\section{Formulation of transdermal patches}

Table 3: Compositions of different formulations containing moronic acid

\begin{tabular}{lllllll}
\hline Formulations & F1 & F2 & F3 & F4 & F5 & F6 \\
\hline Moronic acid, mg & 0.5 & 0.5 & 0.5 & 0.5 & 0.5 & 0.5 \\
Ethylcellulose,mg & 300 & $*$ & 30 & 60 & 90 & 120 \\
HPMC E(5cps),mg & $*$ & 300 & 270 & 240 & 180 & 150 \\
Dibutylphthalate(2drop),ml & 0.12 & 0.12 & 0.12 & 0.12 & 0.12 & 0.12 \\
DMSO,ml & 0.06 & 0.06 & 0.06 & 0.06 & 0.06 & 5 \\
Chloroform: Ethanol(1:1),ml & 5 & 5 & 5 & 5 & 0.12 & 5 \\
\hline
\end{tabular}

*No ingredient used, HPMC=Hydroxypropyl Methylcellulose, DMSO=Dimethyl sulfoxide

Evaluation of transdermal patches

A) Thickness uniformity

Table 4: Thickness uniformity of F1 to F7 patch formulation

\begin{tabular}{|c|c|c|c|c|c|}
\hline \multirow[t]{2}{*}{ S. No. } & \multirow[t]{2}{*}{ Formulation code } & \multicolumn{4}{|c|}{ Average thickness (mm) } \\
\hline & & Trial 1 & Trial 2 & Trial 3 & mean \pm SD \\
\hline 1. & F1 & 0.2 & 0.18 & 0.21 & $0.197 \pm 0.015$ \\
\hline 2. & $\mathrm{~F} 2$ & 0.2 & 0.2 & 0.22 & $0.207 \pm 0.012$ \\
\hline 3. & F3 & 0.19 & 0.21 & 0.22 & $0.207 \pm 0.015$ \\
\hline 4. & F4 & 0.2 & 0.18 & 0.21 & $0.197 \pm 0.015$ \\
\hline 5. & F5 & 0.16 & 0.14 & 0.17 & $0.157 \pm 0.015$ \\
\hline 6. & F6 & 0.21 & 0.22 & 0.19 & $0.207 \pm 0.015$ \\
\hline 7. & F7 & 0.18 & 0.19 & 0.2 & $0.19 \pm 0.01$ \\
\hline
\end{tabular}

Standard deviation, $\mathrm{n}=3$

B) Weight uniformity

Table 5: Weight uniformity of F1 to F7 patch formulation

\begin{tabular}{|c|c|c|c|c|c|}
\hline \multirow[t]{2}{*}{ S. No. } & \multirow[t]{2}{*}{ Formulation code } & \multicolumn{4}{|c|}{ Average weight (mg) } \\
\hline & & Trial 1 & Trial 2 & Trial 3 & mean \pm SD \\
\hline 1. & F1 & 0.4 & 0.43 & 0.41 & $0.413 \pm 0.015$ \\
\hline 2. & $\mathrm{~F} 2$ & 0.38 & 0.36 & 0.37 & $0.37 \pm 0.01$ \\
\hline 3. & F3 & 0.4 & 0.39 & 0.37 & $0.387 \pm 0.015$ \\
\hline 4. & $\mathrm{~F} 4$ & 0.41 & 0.4 & 0.38 & $0.397 \pm 0.015$ \\
\hline 5. & F5 & 0.36 & 0.41 & 0.38 & $0.383 \pm 0.025$ \\
\hline 6. & F6 & 0.39 & 0.34 & 0.36 & $0.363 \pm 0.025$ \\
\hline 7. & F7 & 0.44 & 0.39 & 0.42 & $0.417 \pm 0.025$ \\
\hline
\end{tabular}

$\mathrm{SD}=$ Standard deviation, $\mathrm{n}=3$ 
C) Folding endurance

Table 6: Folding endurance of F1 to F7 patch formulation

\begin{tabular}{|c|c|c|c|c|c|}
\hline \multirow[t]{2}{*}{ S. No. } & \multirow[t]{2}{*}{ Formulation code } & \multicolumn{4}{|c|}{ Folding endurance } \\
\hline & & Trial 1 & Trial 2 & Trial 3 & mean \pm SD \\
\hline 1. & F1 & 117 & 111 & 109 & $112.33 \pm 4.163$ \\
\hline 2. & $\mathrm{~F} 2$ & 54 & 63 & 50 & $55.67 \pm 6.658$ \\
\hline 3. & F3 & 60 & 67 & 73 & $66.67 \pm 6.506$ \\
\hline 4. & F4 & 74 & 84 & 89 & $82.33 \pm 7.638$ \\
\hline 5. & F5 & 85 & 79 & 95 & $86.33 \pm 8.083$ \\
\hline 6. & F6 & 79 & 91 & 84 & $84.67 \pm 6.028$ \\
\hline 7. & F7 & 94 & 104 & 90 & $96 \pm 7.211$ \\
\hline
\end{tabular}

$\mathrm{SD}=$ Standard deviation, $\mathrm{n}=3$

D) Percentage moisture absorption

Table 7: Data of percentage moisture absorption

\begin{tabular}{|c|c|c|c|c|c|}
\hline \multirow[t]{2}{*}{ S. No. } & \multirow[t]{2}{*}{ Formulation code } & \multicolumn{4}{|c|}{ Percentage moisture absorption (\%) } \\
\hline & & Trial 1 & Trial 2 & Trial 3 & mean \pm SD \\
\hline 1. & F1 & 4.65 & 6.99 & 9.3 & $6.98 \pm 2.325$ \\
\hline 2. & $\mathrm{~F} 2$ & 0 & 2.63 & 2.6 & $1.74 \pm 1.510$ \\
\hline 3. & F3 & 0 & 2.95 & 2.95 & $1.97 \pm 1.703$ \\
\hline 4. & $\mathrm{~F} 4$ & 2.7 & 2.7 & 5.55 & $3.65 \pm 1.645$ \\
\hline 5. & F5 & 2.43 & 2.43 & 4.89 & $3.25 \pm 1.420$ \\
\hline 6. & F6 & 2.7 & 5.3 & 5.55 & $4.52 \pm 1.578$ \\
\hline 7. & F7 & 4.769 & 7.142 & 7.142 & $6.35 \pm 1.370$ \\
\hline
\end{tabular}

$\mathrm{SD}=$ Standard deviation, $\mathrm{n}=3$

E) Percentage moisture loss

Table 8: Data of percentage moisture loss

\begin{tabular}{|c|c|c|c|c|c|}
\hline \multirow[t]{2}{*}{ S. No. } & \multirow[t]{2}{*}{ Formulation code } & \multicolumn{4}{|c|}{ Percentage moisture loss (\%) } \\
\hline & & Trial 1 & Trial 2 & Trial 3 & mean \pm SD \\
\hline 1. & F1 & 10 & 13.1 & 15 & $12.7 \pm 2.524$ \\
\hline 2. & $\mathrm{~F} 2$ & 7.92 & 10.52 & 10.54 & $9.66 \pm 1.507$ \\
\hline 3. & F3 & 7.5 & 10.07 & 10.01 & $9.19 \pm 1.467$ \\
\hline 4. & F4 & 2.5 & 5.08 & 7.5 & $5.027 \pm 2.500$ \\
\hline 5. & F5 & 2.85 & 2.85 & 5.79 & $3.83 \pm 1.697$ \\
\hline 6. & F6 & 0 & 5.29 & 7.89 & $4.39 \pm 4.021$ \\
\hline 7. & F7 & 6.97 & 9.31 & 11.62 & $9.3 \pm 2.325$ \\
\hline
\end{tabular}

$\mathrm{SD}=$ Standard deviation, $\mathrm{n}=3$

F) Water vapour transition rate

Table 9: Data of percentage water vapors transition rate

\begin{tabular}{|c|c|c|c|c|c|}
\hline \multirow[t]{2}{*}{ S. No. } & \multirow[t]{2}{*}{ Formulation code } & \multicolumn{4}{|c|}{ Water vapour transition rate $\left(\mathrm{g} / \mathrm{m}^{2} / 24 \mathrm{~h}\right)$} \\
\hline & & Trial 1 & Trial 2 & Trial 3 & mean \pm SD \\
\hline 1. & F1 & 0.0043 & 0.0047 & 0.0046 & $0.0043 \pm 0.0002$ \\
\hline 2. & F2 & 0.002 & 0.0031 & 0.0029 & $0.0027 \pm 0.0006$ \\
\hline 3. & F3 & 0.0026 & 0.0032 & 0.0035 & $0.0031 \pm 0.0005$ \\
\hline 4. & F4 & 0.0029 & 0.0023 & 0.0035 & $0.0029 \pm 0.0006$ \\
\hline 5. & F5 & 0.0035 & 0.003 & 0.0033 & $0.0033 \pm 0.00025$ \\
\hline 6. & F6 & 0.0038 & 0.0034 & 0.0046 & $0.0039 \pm 0.00061$ \\
\hline 7. & F7 & 0.0049 & 0.0045 & 0.0037 & $0.0044 \pm 0.00061$ \\
\hline
\end{tabular}

$\mathrm{SD}=$ Standard deviation, $\mathrm{n}=3$

G) Tensile strength

Table 10: Data of percentage tensile strength

\begin{tabular}{|c|c|c|c|c|c|}
\hline \multirow[t]{2}{*}{ S. No. } & \multirow[t]{2}{*}{ Formulation code } & \multicolumn{4}{|c|}{ Tensile strength $\mathrm{Kg} / \mathrm{mm}^{2}$} \\
\hline & & Trial 1 & Trial 2 & Trial 3 & mean \pm SD \\
\hline 1. & F1 & 3.88 & 3.96 & 3.71 & $3.85 \pm 0.128$ \\
\hline 2. & F2 & 2.86 & 2.98 & 3.07 & $2.97 \pm 0.105$ \\
\hline 3. & F3 & 3.05 & 3.17 & 3.15 & $3.12 \pm 0.064$ \\
\hline 4. & $\mathrm{~F} 4$ & 3.18 & 3.29 & 3.25 & $3.24 \pm 0.056$ \\
\hline 5. & F5 & 3.23 & 3.32 & 3.29 & $3.28 \pm 0.0459$ \\
\hline 6. & F6 & 3.28 & 3.38 & 3.39 & $3.35 \pm 0.061$ \\
\hline 7. & F7 & 3.32 & 3.47 & 3.47 & $3.42 \pm 0.087$ \\
\hline
\end{tabular}

$\mathrm{SD}=$ Standard deviation, $\mathrm{n}=3$ 
H) Drug content

Table 11: Percentage of drug content of F1 to F7 formulation

\begin{tabular}{llll}
\hline S. No. & Formulation & Concentration mean $\pm \mathbf{S D}^{*}\left(\mathbf{m g} / \mathbf{c m}^{2}\right)$ & Percentage drug content $(\%)$ \\
\hline 1. & F1 & $1.178 \pm 0.072$ & 92.67 \\
2. & F2 & $1.058 \pm 0.072$ & 87.69 \\
3. & F3 & $1.084 \pm 0.048$ & 90.27 \\
4. & F4 & $1.085 \pm 0.056$ & 90.28 \\
5. & F5 & $1.117 \pm 0.076$ & 92.88 \\
6. & F6 & $1.116 \pm 0.038$ & 92.87 \\
7. & $1.116 \pm 0.035$ & 95.46 \\
\hline
\end{tabular}

$\mathrm{SD}=$ Standard deviation, $\mathrm{n}=3$

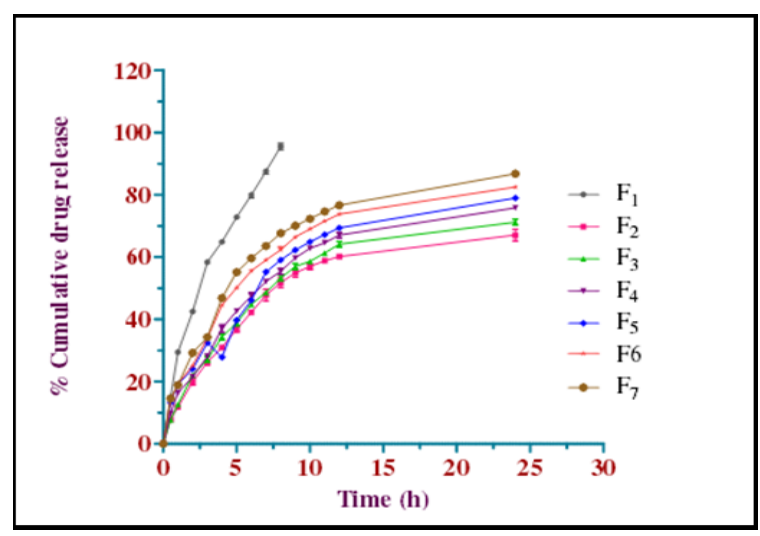

Fig. 6: Comparative in vitro release profile of moronic acid TDDS

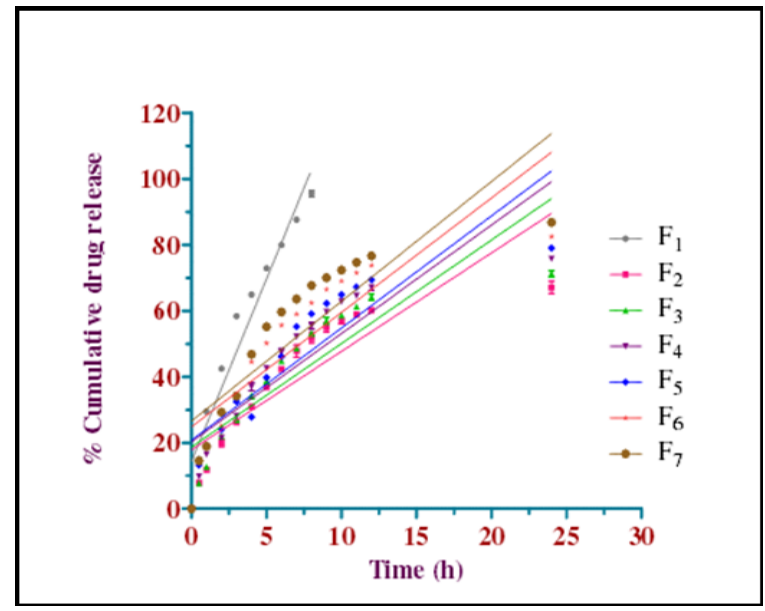

Fig. 7: Comparative in vitro release profile of moronic acid TDDS according to zero-order kinetics

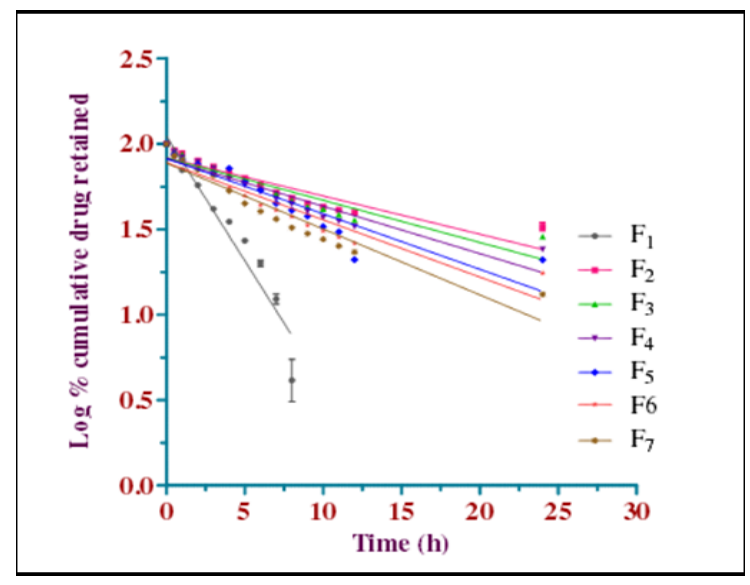

Fig. 8: Comparative in vitro release profile of moronic acid TDDS according to first-order kinetics 


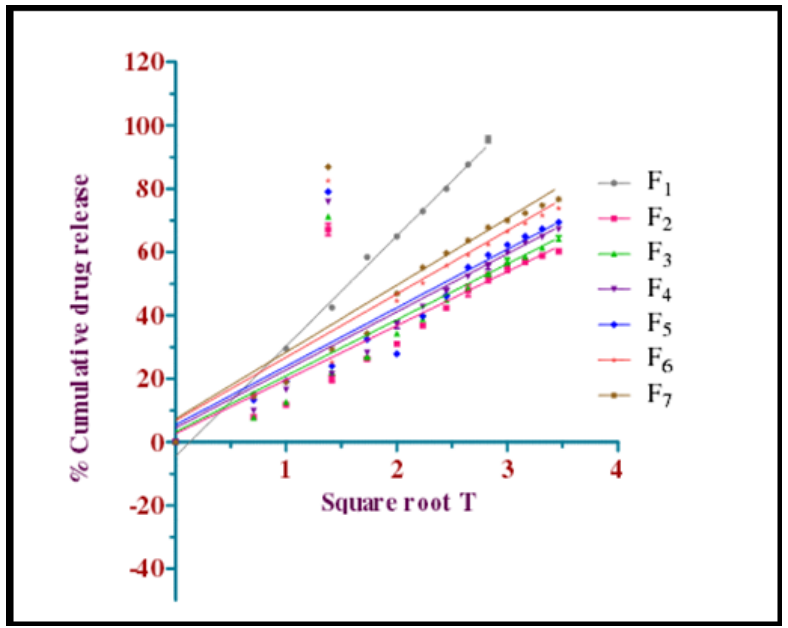

Fig. 9: Comparative in vitro release profile of moronic acid TDDS according to Higuchis plot

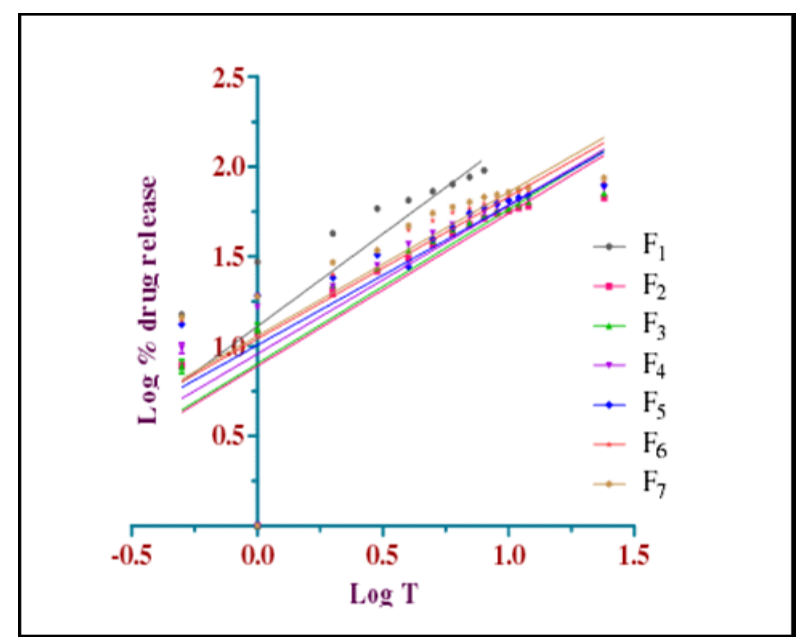

Fig. 10: Comparative in vitro release profile of Moronic acid TDDS according to peppas plot

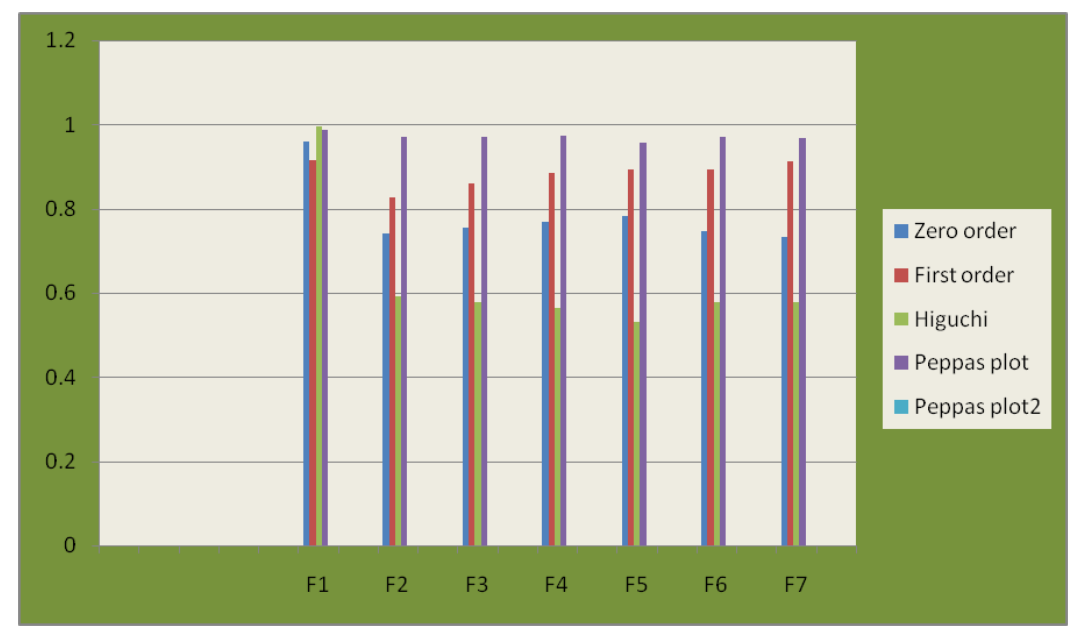

Fig. 11: Graph showing regression coefficient $\left(R^{2}\right)$ values of different kinetics models and diffusion exponent (n) of peppas model for moronic acid TDDS

\section{DISCUSSION}

Transdermal patches were smooth, homogeneous, and flexible. The system preparation approach was deemed acceptable. a) Thickness uniformity: The thickness of the film was measured at several places and the average thickness was recorded. The thickness of the formulations varied from 0.1570 .015 to 0.2070 .015 $\mathrm{mm}$ with minimal standard deviations. 
Weighing three films from the same batch and calculating the average weight. The dry films were digitally weighed. The films were uniformly 0.363-0.417 $\mathrm{g}$ in weight, with a minimal standard variation.

b) Folding endurance: The films folded $>50$ times. It implies all formulations were film-like. The table shows the folding endurance in the following order: $\mathrm{F} 2>\mathrm{F} 3>\mathrm{F} 4>\mathrm{F} 6>\mathrm{F} 5>\mathrm{F} 7>\mathrm{F} 1$ this test measures the sample's folding endurance, which shows brittleness.

d) Percentage moisture absorption: Desiccator research on moisture absorption. All patches absorbed the least moisture. The data are given in the table in the sequence $\mathrm{F} 2>\mathrm{F} 3>\mathrm{F} 5>\mathrm{F} 4>\mathrm{F} 6>\mathrm{F} 7>\mathrm{F} 1(1.74$ 1.510 to 6.982 .325 ). The formulations absorbed little moisture, protecting them against microbial contamination and reducing bulk.

f) Moisture loss: The tests were done at $80-90 \%$ relative humidity. All patches had little moisture loss. The data are given in the table in the sequence $\mathrm{F} 5>\mathrm{F} 6>\mathrm{F} 4>\mathrm{F} 3>\mathrm{F} 7>\mathrm{F} 2>\mathrm{F} 1$ (3.83 1.697 to 12.72 .524 ). The low moisture level in the formulations keeps them from drying out and becoming brittle.

f) WVTR: The prepared patches F1-F7 had a percentage water vapour transfer rate of 0.00270 .0006 to $0.00440 .00061 . \mathrm{g})$ Tensile strength Tensile strength of dibutyl phthalate with dimethylsulfoxide. Both have considerable tensile strength. The mean value ranged from 2.97 to 3.85 $\mathrm{kg} / \mathrm{mm} 2$. The tensile strength findings show the film's strength and breaking danger. However, the plasticizer added to the Transdermal films prevented breaking. Table shows the tensile strength findings.

h) Drug content: The drug content of the different formulations ranged from 1.058 to $1.178 \mathrm{mg}$. This study used a mean quantity of drug present 87.69 to $95.46 \mathrm{mg}$ in each patch to calculate the cumulative percentage drug penetrated and retained.

\section{CONCLUSION}

UV spectroscopy was used to analyse Moronic acid. Moroninic acid (pH 7.4) showed maximum absorption at $215 \mathrm{~nm}$. R2 was 0.992, suggesting a linear relationship between drug concentration and absorbance. In this case, $\mathrm{R} 2=0.998$, which indicates a linear connection between drug concentration and absorbance. It means the patches will be less fragile when applied to the skin and fold well. A little moisture keeps the patch firm and prevents dry, brittle regions. For example, HPMC E5 patches released more than EC patches, perhaps owing to HPMC patches' high water vapour permeability and EC's hydrophobicity. For better and longer release the monolithic system was updated using HPMC E5 and EC. Within 24 h, Formulation F7 with HPMC E5:EC (5:5) released 86.8140.262. Less than a week later, the kinetic simulations verified the release F1-F7 have non-Fickian moronic acid release. Evaporated solventbased moronic acid transdermal patch Studies on healthy animals can evaluate pharmacokinetics. In vitro/in vivo correlation may achieve batch-to-batch stability.

\section{ACKNOWLEDGMENT}

It's our privilege to express profound sense of gratitude and cordial thanks to our respected chairman Mr. Anil Chopra, Vice Chairperson Ms. Sangeeta Chopra and Pro-Chairman Mr. Prince Chopra, St Soldier Educational Society, Jalandhar for providing the necessary facilities to complete this research work.

\section{FUNDING}

Nil

\section{AUTHORS CONTRIBUTIONS}

All the authors have contributed equally.

\section{CONFLICTS OF INTERESTS}

There are no conflicts of interest.

\section{REFERENCES}

1. Wen H, Jung H, Li X. Drug delivery approaches in addressing Clinical Pharmacology-related issues: opportunities and challenges. AAPS J. 2015;17(6):1327-40. doi: 10.1208/s12248015-9814-9, PMID 26276218.

2. Prausnitz MR, Langer R. Transdermal drug delivery. Nat Biotechnol. 2008;26(11):1261-8. doi: 10.1038/nbt.1504, PMID 18997767.

3. Rios MY, Salina D, Villarreal ML. Cytotoxic activity of moronic acid and identification of the new triterpene 3,4-seco-olean-18ene-3,28-dioic acid from Phoradendron reichenbachianum. Planta Med. 2001;67(5):443-6. doi: 10.1055/s-2001-15823, PMID 11488459

4. Qian K, Bori ID, Chen CH, Huang L, Lee KH. Anti-AIDS agents 90. Novel C-28 modified Bevirimat analogues as potent HIV maturation inhibitors. J Med Chem. 2012;55(18):8128-36. doi: 10.1021/jm301040s, PMID 22978745.

5. Khouloud AA, Wasfi MO, Najin MN. Adsorption of allopurinol and ketotifen by chitosan. AAPS PharmSciTech. 2001;2(1):2733. doi: 10.1208/pt020103. PMID: 14727864.

6. Krishnaiah YS, Satyanarayana V, Bhaskar P. Influence of limonene on the bioavailability of nicardipine hydrochloride from membrane-moderated transdermal therapeutic systems in human volunteers. Int J Pharm. 2002;247(1-2):91-102. doi: 10.1016/s0378-5173(02)00401-5, PMID 12429488

7. Sadashivaiah R, Dinesh BM, Patil UA, Deasi BG, Raghu KS. Design and in vitro evaluation of haloperidol lactate transdermal patches containing ethyl cellulose povidone as film formers. Asian J Pharm Sci. 2008;2(1):43-9.

8. Patel HJ, Patel JS, Desai BG, Patel KD. Design and evaluation of amlodipine besilate transdermal patches containing film former. Int J Pharm Res Dev. 2009 Sep;7:1-12.

9. Sathyapriya LS, Jayaprakash S, Prabhu RS, Abirami A, Subramanian K, Nagarajan M. An approach to the formulation and evaluation of transdermal DDS of isoxsuprine $\mathrm{HCl}$. Int J PharmSciTech. 2008 Dec;1(1):22-8.

10. Sankar V, Benito JD, Sivanand V, Ravichandran V, Raghuraman S, Velrajan G. Design and evaluation of nifedipine transdermal patches. Ind J Pharm Sci. 2003;65(5):510.

11. Shivhare UD, Dorlikar VP, Bhusari KP, Mathur VB, Mirani BN Effect of polymeric compositions on pharmacotechnical properties of carvedilol transdermal film. Int J PharmSci Nanotechnol. 2009 Jun;1(2):457-64.

12. Murthy TEGK, Kishore VS. Effect of casting solvent and polymer on the permeability of propranolol hydrochloride through membrane controlled transdermal drug delivery system. Indian J Pharm Sci. 2007 Sep;69(5):646-50. doi: 10.4103/0250474X.38469.

13. Dandagi PM, Manavi FV, Gadag AP, Mastiholimath VS, Jagdeesh T. Formulation of transdermal drug delivery of ketotifen fumarate. Ind J Pharm Sci. 2003;65(3):239-43.

14. https://www.bionity.com/en/encyclopedia/Moronic_acid.HT ML. [Last accessed on 10 Jul 2021]. 